\title{
Exploring the nexus between transdisciplinarity, internationalisation and community service-learning at a university of technology in Cape Town
}

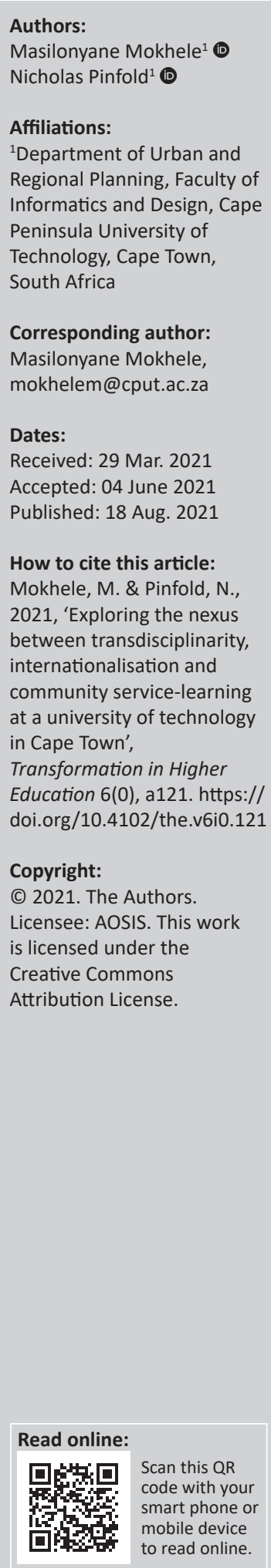

Background: The ability of the South African citizenry to overcome a myriad of challenges (which include the triple challenges of inequality, poverty and unemployment) can be called into question. This alleged inability could, in part at least, be linked to the role of higher education, which is at a vantage point of equipping the citizenry with the requisite values, skills and knowledge.

Aim: The aim of the article is to discuss attempts that were employed towards imparting transdisciplinary and collaborative skills to students at Cape Peninsula University of Technology (CPUT).

Setting: The article reports on the collaboration between a number of stakeholders, viz. CPUT, University of Michigan, St. Mark's Church and District Six Museum. The aim of the collaboration was to develop an interactive Web map, which would display the socio-spatial information based on the baptismal records of the former residents of District Six.

Methods: The article explores interconnections between transdisciplinary education, internationalisation of higher education and community service-learning. The discussion is based on the authors' reflective analysis of the deployment of the triad of concepts in the initiative reported on.

Results: Intricate interdependencies were discovered between transdisciplinarity, internationalisation of higher education and community service-learning.

Conclusion: It is proposed that future teaching and learning initiatives employ a critical lens and the notion of complexity to meticulously explore the aforesaid concepts towards extending the frameworks for higher education.

Keywords: higher education; internationalisation of higher education; transdisciplinary education; community service-learning; South Africa; Cape Peninsula University of Technology; University of Michigan.

\section{Introduction}

A multitude of countries across the globe, particularly those in the global South, experience a myriad of challenges, stresses and shocks, which include the ramifications of climate change, high levels of unemployment, poverty, inequality and pandemics that ravage the world at different times in history. Characterised by the so-called triple challenges of inequality, poverty and unemployment (Akanbi 2016a, 2016b; Mzangwa 2016; Statistics South Africa 2013; Van der Westhuizen \& Swart 2015), South Africa is definitely no exception. Given that the triple challenges are on the perpetual rise in the country (Statistics South Africa 2013), the ability and efficacy of the South African citizenry to overcome the multifaceted challenges can be put into question. Interrelated factors that could be responsible for this state of affairs include the following: (1) corruption and/or misuse of public funds (World Bank 2018), (2) ineffective governance and leadership (Mzangwa 2016) and (3) inappropriate physical and institutional infrastructures (Akanbi 2016b). Another related factor that could in part be responsible for this situation (and arguably embedded in some of the considerations here) is that whilst stakeholders may work together in addressing particular problems, they struggle to look beyond their disciplines and inadvertently work in silos. This rigidity could be related to the role of higher education. In the age where higher education is expected to continually evolve in response to complex problems that the changing world encounters (Kromydas 2017:2; Ramaley 2014:7), it can be argued that higher education institutions are at a vantage point of equipping the citizenry with the requisite 
knowledge and skills for collaboratively analysing societal issues and accordingly contributing towards their resolution. Increased public attention is specifically drawn to the higher education fraternity in the light of its pivotal role in knowledge generation, augmentation, conservation and dissemination (Kehm \& Teichler 2007).

Notwithstanding the aforementioned significance of education and training in equipping the citizenry with the essential knowledge and skills, there is lack of literature regarding ways the South Africa's higher education sector collaborates with communities and allied stakeholders towards implanting the culture of collaboration in students and in the process reconsider what it means to be educated in the ever-changing world (Ramaley 2014:8). Revolving around Cape Peninsula University of Technology (CPUT) in Cape Town, South Africa, the aim of this article is to present efforts that were undertaken by higher education institutions and allied stakeholders to lay the building block for collaboration and social consciousness in university students. The initiative that the article is based upon inadvertently explored interconnections between a triad of concepts, namely transdisciplinary education, internationalisation of higher education and community service-learning as defined herein. To the best of our knowledge, interconnections between these concepts have not been explicitly acknowledged and systematically unpacked in the existing literature on higher education in South Africa. As evidenced by the literature cited herein, the existing studies tend to analyse the said concepts independently of one another. Although each concept is useful in its own right, the nexus between them is the realm of knowledge that the article intends to contribute towards.

Subsequent to this introduction, the rest of the article is organised in five sections as follows: the second section provides an overview of the methods used in compiling the article, including a snapshot of the setting of the initiative that is reported on. The third section defines the underlying concepts of transdisciplinary education, internationalisation of higher education and community service-learning; whilst simultaneously indicating how these concepts were employed in the initiative reported on. The fourth section synthesises the project reported on against the interconnections between the three concepts. The penultimate part (Section Five) builds upon the synthesis to advance recommendations on the foundations for a framework that could be used to guide future service-learning initiatives. The sixth section concludes the article and suggests areas for future research.

\section{Methods and setting of the project}

The article reports on a teaching and learning initiative that focussed on the topical neighbourhood of District Six in Cape Town, South Africa. As further discussed hereunder, the area is one of the quintessential examples of the aftermath of apartheid. It is important to emphasise at the outset that the initiative was not designed and implemented for research purposes or meant to be reported on and shared in the manner of this article. Given that the idea of drafting this article was essentially an afterthought, CPUT team had not applied for ethics clearance from relevant committees of the university. As such, besides naming the institutions involved in the initiative, sensitive information (such as the names of students, church leaders and community members) is not disclosed in the article. The account herein provides a retrospective reflection of the processes and activities that were undertaken in the initiative that emerged and evolved organically in 2018 and 2019. The writing mode employed in the article has resemblance to the so-called 'storytelling' (Maynes, Pierce \& Laslett 2008; Van Hulst 2012; Watson 2002), which relays the narrative of how the nexus between the concepts of transdisciplinarity, internationalisation of higher education and community service-learning was inadvertently teased out in the initiative reported on. The article refers to the initiative as either St. Mark's Church project or District Six project. As other aspects of the initiative are discussed elsewhere (refer to Pinfold \& Mokhele 2019), the article overviews the origins, aim, evolution and other aspects of the project so far as they pertain to interconnections between the underlying triad of concepts. The discussion culminates in the exploration of how the fortuitous experience could be improved upon and be used as foundation for future higher education teaching and learning endeavours.

Resulting from intricate academic and social networks, the initiative included higher education institutions in South Africa and the United States of America (i.e. different faculties and departments of CPUT in South Africa and University of Michigan in the United States of America), St. Mark's Church and District Six Museum. The aim of the collaboration was to sensitise the students to the history of District Six and ultimately develop an interactive Web map, which would display (on the District Six Museum's website) socio-spatial information based on the baptismal records of the former residents of District Six. Anticipated to be openly accessible in the public domain, it was intended that the Web map would, amongst others, be used to enlighten local and international communities on the socio-cultural history of District Six and accordingly provide the former residents a platform to take a trip down memory lane (Cox et al. 2019). Typifying the footprint of the apartheid regime, the original District Six neighbourhood was demolished by the then government, the community was dismantled and a multitude of households were displaced to various locations in the Cape metropolitan area. St. Mark's Church was one of a few structures (mainly religious institutions), which were spared. Following the dawn of democracy in 1994, efforts by the government to return the former residents to their beloved District Six have however been extremely slow wherein only a few families have thus far returned to the area. The memories and stories of some of the last generation of people who were displaced at the height of apartheid would indeed go a long way in documenting, preserving, memorialising and sharing the rich history of District Six. 
Against this backdrop, after much deliberation, the aforementioned stakeholders agreed that the scope of the initiative would entail three main elements: (1) collection and analysis of social and geospatial information from the baptismal records kept by St. Mark's Church, (2) deployment of geographic information system (GIS) and associated technological tools and techniques to capture, process and display the said data as a Web map and (3) collection of the stories of the former residents of District Six so far as they related to the selected community members on the baptismal records analysed and ultimately integrating those personal tales into the Web map (Pinfold \& Mokhele 2019).

\section{An overview of internationalisation, transdisciplinarity and community service-learning}

As observed in the Methods and Setting of the Project above, the educational initiative that the article reports on was inadvertently based on interconnections between the concepts of transdisciplinary education, internationalisation of higher education and community service-learning. In this regard, the outline presents a synopsis of the three concepts, portrays their relevancy in higher education, highlights CPUT's general position as a point of reference and shows how each concept was applied in the initiative that the article revolves around.

\section{Community service-learning}

Although the origins of community service-learning cannot be identified with accuracy, some scholars posit that the term service-learning was coined in the 1960s (Giles \& Eyler 1994:78) to denote a particular form of partnership between communities and universities. Community service-learning affords students an opportunity to collaboratively work with community members on projects that would in one way or another be of benefit to a given community. This type of learning intends to develop the analytical and problem-solving skills of students, trains them to adjust and function in challenging, unpredictable environments (Sletto 2010) and accordingly provides students with social aspects of knowledge generation (Elwood 2004). It is believed that community servicelearning contextualises the production of knowledge through educating students in society's problems (Conner \& Erikson 2017; Hall 2010; Petersen \& Osman 2017; Thomson et al. 2011). In this way, the meaning of being educated shifts as it relates in the main to the ability of students to engage and work with communities towards analysing and in part resolving particular challenges. In this teaching and learning pedagogy, the students move from the comfort zone of a classroom or university campus to learn directly from communities.

As a point of reference to the initiative that the article reports on, it should be observed that CPUT regards community engagement as programmes provided by the university that involves collaboration with external organisations, groups and individuals towards realising social and economic objectives. This collaboration is fulfilled through teaching and learning, research, community service-learning and cooperative education (CPUT n.d.). Against this backdrop of a broad understanding of community engagement, community service-learning at CPUT is a credit-bearing educational endeavour in which students participate in organised activities that respond to identified community needs. The credit-bearing aspect of the pedagogy means that community service-learning has to be embedded in the curriculum and the assessment strategies of the relevant subjects. Given the complicated and time-consuming nature of community service-learning projects, CPUT has a dedicated unit, which acts as a primary liaison in partnerships between university staff and communities and accordingly supports academic departments at the university with the logistics pertaining to service-learning projects (Scheepers 2014).

As part of a community service-learning process, students from CPUT and Michigan University provided their respective disciplinary input towards the collection, analysis and visualisation of baptismal data at different stages of St. Mark's Church initiative. In the spirit of service-learning, the project was meant to practically educate the students on the nuances of collaborating with community partners; whilst the students also assisted the community towards achieving their aspiration of creating a Web map and capturing personal stories. The initiative was registered as a service-learning project as required by the university. The collaboration between the students from CPUT, University of Michigan and the former residents of District Six was mainly through St. Mark's Church and District Six Museum where discussions and related activities were facilitated and held. As elaborated further in the subsequent sections, collaboration involving academic staff and students with diverse disciplinary backgrounds (at different levels of study) provided a unique, rich learning experience, as well as fertile foundation for revisiting the notion of being educated in the contemporary world.

\section{Internationalisation of higher education}

Institutions of higher learning establish international linkages with each other for several reasons, but more often than not they create alliances to be able to survive, adapt, remain relevant and compete in the ever-evolving higher education realm (Chan 2004:32). Internationalisation of higher education is however a highly ambiguous concept, which can be construed differently depending on context and time (Knight 2004:5; Meda \& Monnapula-Mapesela 2016:283). Nonetheless, contemporary definitions of internationalisation largely draw on the seminal work of Knight (2004). For instance, building on Knight's foundation, De Wit and Hunter (2015:3) defined internationalisation as a process of mixing an intercultural and international aspects into the purpose and supply of post-secondary education to improve the value of education and research for students and staff, with the ultimate aim of contributing meaningfully to society's welfare. This definition accentuates that 
internationalisation is a medium for enhancing the quality and relevance of higher education rather than a goal in itself (De Wit \& Hunter 2015:3). As alluded to here, internationalisation of higher education is diverse and multidimensional (Wu \& Zha 2018:273), resulting in non-mutually exclusive standpoints to internationalisation. Firstly, in some circles, internationalisation means a range of international activities, for example, joint projects, partnerships, international linkages, mobility for students and/or academic staff and research initiatives. Secondly, internationalisation could imply the provision of higher education internationally through arrangements such as distance learning or campus face-to-face learning methods. Thirdly, in some instances, internationalisation could mean the incorporation of intercultural, international or global aspect into the curriculum and subsequent teaching processes and activities (Knight 2004). This diversity and multidimensionality accordingly bring to the fore a number of related typologies of internationalisation of higher education, including the following: (1) internationalisation at home, wherein the approaches include relationships with local community groups, international and intercultural aspects in teaching and learning, extracurricular activities, research and integrating academic staff and students from other universities, (2) cross-border education signifying the movement of programmes, policies, education providers, knowledge, projects and services and ideas across national borders (Knight 2012 as cited in Wu \& Zha 2018:261).

Cape Peninsula University of Technology embraces the concept of internationalisation of higher education, which is typified by the slogan 'smart internationalisation'. As part of a strategic plan for internationalisation of higher education, the so-called smart internationalisation is a manifestation of CPUT's commitment to the strategic value of the university's internationalisation efforts in achieving and sharing the advancements in technology and innovation and collaboratively blurring the lines between the university and its partners towards the achievement of multicultural and intra-national communities of practice for the mutual benefit and sustainability of the global environment (CPUT 2019). As a common practice across universities, CPUT has a dedicated 'strategic initiatives and partnerships' office, whose objectives include the identification, development and management of national and international partnerships, which enhance the attainment of the university's research, technology and innovation strategy.

Against this backdrop, students from University of Michigan sojourned in Cape Town (in two groups in 2018 and 2019, respectively) to jointly work with CPUT students and other stakeholders in the project. Students from the University of Michigan were part of the 2018 and 2019 Global Information Engagement Program (GIEP) facilitated by their university. Global Information Engagement Programme aimed to explore the intricate relationships amongst people, information and various forms of technology. Upon their arrival in Cape Town, University of Michigan students learnt about the diverse cultures and history of South Africa particularly in so far as District Six was concerned. In a true spirit of collaboration, the students did not bring preconceived ideas to the project and were accordingly willing to learn from other stakeholders. Different skills were subsequently transferred (formally and informally) between the South African and American students and academic staff at different stages of the project.

\section{Transdisciplinary education}

As is the case with internationalisation of higher education, transdisciplinarity is difficult to define with precision (Nicolescu 2010). Definitions of the various concepts of disciplinary collaboration tend to be confused with each other, hence the definition of transdisciplinarity needs to be considered relative to the associated concepts, (Gehlert et al. 2010) that is, interdisciplinarity and multidisciplinarity. According to Nicolescu (2014:187), the concepts are complementary and not in opposition to each other. Interdisciplinarity is dependent on individual discipline's concepts, methods, theories and techniques in understanding and addressing a particular problem. Although the underlying process is largely informed by the frameworks and methods of one discipline, methods from other disciplines are acknowledged (Leavy 2011; Repko 2008). Multidisciplinarity is the combination of a variety of disciplines in answering a given question or resolving a particular problem. Insights from various disciplines are brought together without trying to fundamentally fuse them (Leavy 2011; Repko 2008; Wall \& Shankar 2008).

In transdisciplinarity, members with diverse disciplinary backgrounds (students and stakeholders in the context of the article) collaborate, providing methods that go beyond the views of individual disciplines (Stokols et al. 2010; Wall \& Shankar 2008). In doing so, experiences, knowledge, ideas, values and expectations are exchanged (Du Plessis, Sehume \& Martin 2014). Shared frameworks are developed by academics, professionals and/or researchers in a transdisciplinary approach when addressing a particular problem (Stokols et al. 2010). Transdisciplinarity is based on the principle that reality is too complex, intricately connected and multidimensional. This supports the proposition of using multiple disciplines in analysing reality (Du Plessis et al. 2014; Martin 2017) and finding solutions to a specific problem (Hoffman-Riem et al. 2008) in collaboration with non-academic interested and affected parties (Palmer, Owens \& Sparks 2006).

Contrary to community service-learning and internationalisation of higher education, CPUT does not yet have a policy, framework or at least a publicised position on transdisciplinary education. However, typical of catchwords, the word 'transdisciplinarity' tends to be mentioned here and there at CPUT. Notwithstanding the lack of overarching university guidance, the Department of Urban and Regional Planning had conducted some exploratory work on transdisciplinary education prior to the District Six initiative (see Mokhele \& 
Pinfold 2020). It should further be observed that regardless of the lack of clear position on transdisciplinary education, the academic structure of CPUT makes provision for students to enrol in subjects across departments and faculties. However, the crossover (which is arguably a crucial part of transdisciplinarity) is not practised in earnest at the university (Mokhele \& Pinfold 2020:4).

As regards the initiative that the article reports on, approximately 117 students from 2 faculties (Faculty of Informatics and Design and Faculty of Engineering and Built Environment) and 2 departments (Urban and Regional Planning and Geomatics, respectively) of CPUT and 7 students from various departments of University of Michigan participated in St. Mark's Church project in 2018 and 2019. The activities of the project were linked to the respective disciplinary subject requirements of the departments and universities. As alluded to here, the students did not enrol in subjects across departments, faculties and universities. University of Michigan students were from diverse disciplines, including information science, social work, public policy and urban planning. They were also studying at different levels ranging from undergraduate degrees to doctoral programmes. As noticed in the preceding section, students from University of Michigan were part of the 2018 and 2019 GIEP programme, whose aim was to explore the relationships and interconnections between people, information and technology; hence it was anticipated that the students would learn from the project whilst also providing valuable input and sharing their knowledge for the realisation of the aim of the project. During their stint in Cape Town, University of Michigan students worked closely with the Department of Urban and Regional Planning where they were offered a dedicated working space with the necessary computer infrastructure. The students also had a working space at the District Six Museum (Pinfold \& Mokhele 2019).

The participants from CPUT included academic staff and first-year and third-year students completing the diplomalevel qualifications in Urban or Town and Regional Planning and third-year students enrolled in the National Diploma in Geomatics. With the project largely related to mapping the socio-spatial history, the project activities were associated with the so-called 'technology-related' subjects at CPUT. To reflect this state of affairs, Urban and Regional Planning firstyear students were enrolled in the subject named 'Information Systems' whilst third-year students were completing the subject 'Geographic Information Systems'. In that specific subject, students learn ways to analyse numerical information in a spreadsheet and relate tables using database management systems. Students are particularly taught to ascertain what data are needed for particular problems and how the data could be collected, organised and disseminated. The practical part of the subject teaches students the rationale and processes of applying computer-aided design (CAD) in urban planning. Geographic information systems deal with spatial concepts, spatial analysis and geospatial information. The subject consists of practical lessons where students use both commercial and open-source GIS software. The practical assignments require a significant commitment that takes time. Group work is required to encourage peer learning and to introduce the spirit of collaboration. The subject prepares students as planning technicians who work in private sector, non-governmental sector and government (Pinfold \& Mokhele 2019).

Although not wittingly and meticulously designed and setup as such, a transdisciplinary space emerged in the attempts towards integrating the various disciplines and providing shared meaning and connection to the socio-spatial history of District Six. This integration was meant to provide an opportunity for groups with diverse disciplinary perspectives to contribute to the process whilst willing to learn from the standpoint of fellow project members.

\section{A synthesis of St. Mark's Church project}

Intricate overlaps that exist between the concepts of internationalisation of higher education, transdisciplinary education and community service-learning are apparent in the overview and application of the concepts in the preceding section. This is the space that the article attempted to explore relative to St. Mark's Church initiative in District Six (Figure 1).

St. Mark's Church initiative incorporated both horizontal and vertical dimensions of collaboration in the learning and sharing of diverse disciplinary knowledge and the inherent codified and tacit knowledge. On the one hand, the students who participated in the project were enrolled at different levels of study at the respective universities: from the first year and third year of diploma qualifications to the apex of

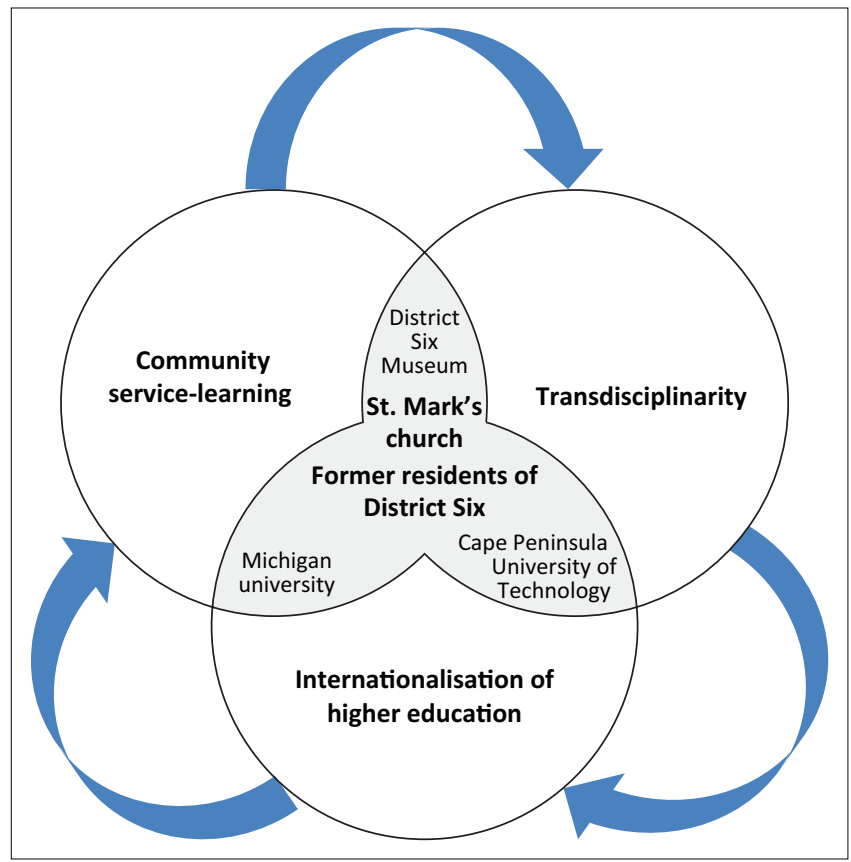

FIGURE 1: Nexus between service-learning, transdisciplinary education and internationalisation. 
doctoral level. This embodied vertical integration. In the resultant teaching and learning milieu, no particular students or groups of students were considered superior notwithstanding their level of study, programme of study or country of their institutions. On the other hand, and relatedly, horizontal integration was realised in that the students came from various programmes of study, and got acquainted with different disciplinary knowledge, methods, techniques and processes. Horizontal integration also blurred international borders and socio-cultural disparities as the initiative included students from two countries on different continents.

At the heart of the initiative was the strive to assist the community (represented by the former residents, St. Mark's Church and District Six Museum) wherein the students explicitly and tacitly learned about academic disciplines other than theirs. The two groups of students also got acquainted with the history and cultures of South Africa, and particularly the socio-spatial realities of the community of District Six, which was destroyed by the apartheid government. Significantly, the students had a rare opportunity to learn about the community needs directly from the horse's mouth instead of participating in the project with preconceived ideas on what the needs and expectations of the community were. The students in the process learnt to interrogate, navigate and respond to the requirements and expectations of community members and/or their representatives.

St. Mark's Church project had elements of engagement, knowledge-building and involvement in community activism. Stakeholders of different ages and backgrounds participated in discovering historical and contemporary issues of identity and intersectionality pertaining to District Six. Through dialogue and collaborative partnering, the students were able to apply theoretical knowledge in a real community setting. The collaborative partnering resulted in knowledge cocreation, citizen empowerment, engagement and the promotion of social justice and resilience. The action-oriented experiential nature of the project allowed students with different academic backgrounds to gain common skills in community engagement. It prompted critical thinking about facts (and fiction), the stories people tell and the reasons such stories are important. The process taught students flexibility and creativity towards capturing and analysing knowledge as it arose. Internationalisation encouraged the students to articulate the opportunities and navigate barriers to collaboration. Students from the United States of America were confronted with the challenge of visualising community facts, values, visions, stories and geographic information in an unfamiliar context. In these circumstances, the students needed to be comfortable, adjust and deliver a co-constructed representational outcome that had a direct bearing on the community of District Six. This required collective thinking, open-mindedness and willingness to engage thoughtfully, creatively and flexibly within their group and with the community members. Each student brought their unique passion, experience, consciousness and social justice considerations. Kindness, patience and the ability to listen were therefore some of the skills that the students developed and/or imparted. The students' diversity in terms of identity, background and perceptions about community places provided enhanced learning for all the students.

Teaching and learning activities in the initiative included lectures, addresses by guest speakers, discussions, brainstorming and problem-solving sessions, field trips, community-engaged exercises and teamwork on community-based mapping. In general, 1 day a week was spent in class learning about community mapping methods and matters pertaining to ethics, particularly when engaging with community members. The rest of the week involved collaborative work with the community and/or its representatives. Students were also assessed on their willingness to engage and reflect in class and their active contribution to the team's work. Each team member was expected to contribute in their own way towards the achievement of the project aim and expected to share the information and communicate effectively at all times with fellow team members. Together, the students focussed on a mosaic of self-contained mapping exercises that directly contributed to a greater picture and a more collaboratively developed outcome. Teams of students were responsible for developing and nurturing community relationships, listening and facilitating knowledge gathering, co-creation and appropriate presentation of findings.

\section{Towards a framework for the internationalisation of critical transdisciplinary community service-learning}

A number of scholars (e.g. Battistoni 2000; Gardinier 2017a) argue that the pedagogy of community service-learning is not apolitical. Against this backdrop, instead of continuing on the trajectory of traditional approaches, Mitchell (2008) advocated for a critical stance to service-learning. The literature therefore unpacks critical service-learning in contradistinction to charity-oriented approaches that do not necessarily work towards fundamental changes in society (Kinefuchu 2010:78). Acknowledging the importance of structural analysis of society (Gardinier 2017a), critical service-learning cultivates a culture of consciousness in students by giving them a platform to examine significant historical occurrences in the communities that universities collaborate with. All in all, the critical approach allows students to become aware of the various forms of oppression and inequalities that exist in society. The overarching aim of university-community collaborations should therefore be to bring to the fore the political nature of a pedagogy that sensitises students towards the dismantling of inequality and oppression in the long term (Mitchell 2008:54).

Marullo (1999) as cited in Mitchell (2008:62) argued that critical service-learning has potential to develop the citizenry, activists and leaders who are committed to the promotion of a socially just world. In this regard, the proponents of critical service-learning advocate for the transformation of students 
and society through carefully identified, well planned and systematically implemented service-learning initiatives. Whilst it is acknowledged that critical service-learning approach may be difficult to implement within the confines of society and higher education institutions that may not be amenable to fundamental social change, the relevancy and potential of this pedagogy call for it to be the future direction of service-learning initiatives (Mitchell 2008).

Having resemblance to critical service-learning, the aim of District Six project was not only to develop a Web map but also to sensitise the South African and American students on the socio-spatial history of South Africa and District Six. As discussed throughout the article, this history is intertwined with the ramifications of the unjust political system of apartheid; hence it is argued that the project brought the apolitical nature of service-learning to the fore. In the process, the former residents of District Six (who were oppressed during apartheid) were given a platform to tell their stories. Learning from the District Six project, it is recommended that future service-learning initiatives in South Africa and beyond focus on areas that have particular political and social significance. This would sensitise students and the citizenry to the long-lasting ramifications of political systems and how the problems can be circumvented or resolved.

The article argues that the approach of critical servicelearning should be framed against the notion of complexity, which can be viewed in two ways, viz. complex problems that higher education tries to unravel and challenges or complexities encountered in the delivery of critical servicelearning initiatives. As noticed earlier in the section on the overview of concepts, tackling complex social issues using a single-discipline approach tends to downplay or misconceive complexity. A complexity-based approach is thus needed to avoid a mistake of isolating a single variable in favour of a network of interconnecting events, individuals and the underlying relationships. This approach brings to the fore the notion of transdisciplinarity, which the article argues is useful for unpacking complexity because it transcends individual disciplinary boundaries (Montuori 2013:47). In this regard, arguably the most effective way of analysing complexity is through collaborating with partners who have similar interests and objectives within the ambit of critical service-learning.

With relevance to service-learning and transdisciplinary education, Martin and Pirbhai-Illich (2015) as cited in Gardinier (2017b:66) advance a framework for classifying ideologies and associated educational aims for global servicelearning (GSL), which has resemblance to our notion of the internationalisation of service-learning. The argument raised in the article is aligned with Martin and Pirbhai-Illich's (2015) critical ideology of GSL, whose educational aim is to develop the citizenry that are critical of systems and processes that perpetuate injustice and inequalities in society. It is hoped that with such consciousness, the citizenry would strive in the long run to unsettle the unjust systems (Martin \& PirbhaiIllich 2015 as cited in Gardinier 2017b:66).
Drawing lessons from the District Six project, it is recommended that future initiatives adopt a critical orientation to underpin and bind community servicelearning, transdisciplinary education and internationalisation of higher education. Although it is not ideal to make normative assertions on the basis of one case study, the District Six project showed that the pedagogy of internationalised critical transdisciplinary community service-learning is feasible. Future initiatives can therefore build upon this experience through identifying projects that have potential to make meaningful contribution and in the long term bring social change in society.

\section{Conclusion}

A number of scholars maintain that there is a need to rethink the meaning of education in the world that faces a number of challenges (e.g. Ramaley 2014). In this regard, collaborative efforts are required between stakeholders with different disciplinary backgrounds and with community members. Tackling complex social issues using a single-discipline approach tends to ignore or misconceive complexity. A complexity-based approach is thus needed to avoid isolating a single factor at the expense of a network of interconnecting events, individuals and fundamental relations (Montuori 2013:47). Against this backdrop, the article presented an organic way in which CPUT and University of Michigan collaborated with St. Mark's Church, District Six Museum and selected former residents of District Six to at least in part lay a foundation for transdisciplinarity and community service-learning. This collaboration sensitised the students to the ramifications of apartheid and culminated in the successful implementation of a preliminary Web map on the District Six Museum's website. Although the actual activities of the initiative reported on are not novel per se, as a contribution to the extension of existing literature on higher education, the article explored the nuanced interconnections between the concepts of transdisciplinary education, internationalisation of higher education and community service-learning through the use of a critical lens. The teasing out of this nexus could contribute towards inculcating the skills, consciousness and values required for analysing and resolving some of the socio-economic challenges (epitomised by the so-called triple challenges) in South Africa and beyond. It is hoped that future efforts would further explore the interconnections and systematically integrate them into the curricula, policy and frameworks of the institutions involved. This critical nexus can ultimately be of importance towards extending the theoretical and practical aspects of what we refer to as internationalisation of critical transdisciplinary community service-learning'.

It should however be declared that one of the limitations of the article is that it does not incorporate the voice and views of the students and/or community members on the efficacy of the educational approach employed. To solidify the argument presented in the article, it is suggested that future research integrates ex postengagement with thestakeholders (community, students and university staff) to critically decipher the nature 
and level of the benefits derived from the internationalised critical community service-learning pedagogy and the complexities and challenges encountered. With such comprehensive assessment, the approach proposed in the article could be systematically tested in different contexts and potentially be developed into one of the quintessential frameworks or dimensions of internationalisation of higher education. This would indeed contribute towards rethinking, reimagining and redesigning the notion of what it means for the citizenry to be educated in the realm of contemporary higher education.

\section{Acknowledgements Competing interests}

The authors declare that they have no financial or personal relationships that may have inappropriately influenced them in writing this article.

\section{Authors' contributions}

All authors contributed equally to this work.

\section{Ethical considerations}

This article followed all ethical standards for research without direct contact with human or animal subjects.

\section{Funding information}

This research received no specific grant from any funding agency in the public, commercial or not-for-profit sectors.

\section{Data availability}

Data sharing is not applicable to this article as no new data were created or analysed in this study.

\section{Disclaimer}

The views and opinions expressed in this article are those of the authors and do not necessarily reflect the official policy or position of any affiliated agency of the authors.

\section{References}

Akanbi, O.A., 2016a, 'The growth, poverty and inequality nexus in South Africa: Cointegration and causality analysis', Development Southern Africa 33(2), 166-185. https://doi.org/10.1080/0376835X.2015.1120654

Akanbi, O.A., 2016b, 'Addressing Africa's triple challenges: To what extent do physical and institutional infrastructures matter', Inaugural lecture, Department of Economics, University of South Africa, viewed from http://uir.unisa.ac.za/ bitstream/handle/10500/21896/Inaugural\%20Lecture_Akanbi... pdf?sequence=1\&isAllowed $=\mathrm{y}$.

Battistoni, R.M., 2000, 'Service learning in political science: An introduction', PS Political Science and Politics 33(3), 614-616. https://doi.org/10.2307/420866

Chan, W.W.Y., 2004, 'International cooperation in higher education: Theory and practice', Journal of Studies in International Education 8(1), 32-55. https://doi. org/10.1177/1028315303254429

Conner, J. \& Erickson, J., 2017, 'When does service-learning work? Contact theory and service-learning courses in higher education', Michigan Journal of Community Service Learning 23(2),53-65.https://doi.org/10.3998/mjcsloa.3239521.0023.204

Cox, V., Dall, V., Qiu, V. \& Yelk, J., 2019, District Six Museum St. Mark's memory capture and interactive mapping, Project Report.

CPUT (Cape Peninsula University of Technology), 2019, Smart internationalisation: Strategic plan, 2020-2025, CPUT, Cape Town, viewed 5 July 2019, from https:// www.cput.ac.za/research-technology-and-innovation/internationalisation-2020.
CPUT (Cape Peninsula University of Technology), Centre for community engagement and work integrated learning (CCEWIL), viewed 04 May 2021, from https://www. cput.ac.za/services/ccewil.

De Wit, H. \& Hunter, F., 2015, 'The future of internationalization of higher education in Europe', International Higher Education 83(Special edition), 2-3. https://doi. org/10.6017/ihe.2015.83.9073

Du Plessis, H., Sehume, J. \& Martin, L., 2014, The concept and application of transdisciplinarity in intellectual discourse and research, Real African Publishers, Woodmead.

Elwood, S.A., 2004, 'Experiential learning, spatial practice, and critical urban geographies', The Journal of Geography 103(2), 55-63. https://doi. org/10.1080/00221340408978576

Gardinier, L., 2017a, 'Mind-set, critical theory, and the ethics of engagement', in L. Gardinier (ed.), Service-learning through community engagement, pp. 151-164, Springer, New York, NY.

Gardinier, L., 2017b, 'Global community engagement: Transformation, paradoxes and fumbling forward', in L. Gardinier (ed.), Service-learning through community engagement, pp. 57-69, Springer, New York, NY.

Gehlert, S., Murray, A., Sohmer, D., McClintock, M., Conzen, S. \& Olopade, O., 2010, 'The importance of transdisciplinary collaborations for understanding and resolving health disparities', Social Work in Public Health 25(3-4), 408-422. https://doi.org/10.1080/19371910903241124

Giles, D.E. Jr. \& Eyler, J., 1994, 'The theoretical roots of service-learning in John Dewey: Toward a theory of service-learning', Michigan Journal of Community Service Learning 1(1), 77-85.

Hall, M., 2010, 'Community engagement in South African higher education', in The South African council on higher education (ed.), Community engagement in South African higher education, pp. 1-52, Jacana Media, Pretoria.

Hoffman-Riem, H., Biber-Klemm, S., Grossenbacher-Mansuy, W., Hardon, G.H., Pohl, D.C., Wiesmann, U. et al., 2008, 'Idea of the handbook', in G.H. Hardon, H. Hoffman-Riem, S. Biber-Klemm, W. Grossenbacher-Mansuy, D. Joye, C. Pohl, et al. (eds.), Handbook of transdisciplinary research, pp. 3-17, Springer, Bern.

Kehm, B.M. \& Teichler, U., 2007, 'Research on internationalisation in higher education', Journal of Studies in International Education 11(3-4), 260-273. https://doi. org/10.1177/1028315307303534

Kinefuchu, E., 2010, 'Critical Consciousness and Critical Service-Learning at the Intersection of the Personal and the Structural', Journal of Applied Learning in Higher Education 77-93, viewed n.d., from https://files.eric.ed.gov/fulltext/ EJ1188509.pdf

Knight, J., 2004, 'Internationalization remodelled: Definitions, approaches, and rationales', Journal of Studies in International Education 8(1), 5-31. https://doi. org/10.1177/1028315303260832

Kromydas, T., 2017, 'Rethinking higher education and its relationship with social inequalities: Past knowledge, present state and future potential', Palgrave Communications 3, 1. https://doi.org/10.1057/s41599-017-0001-8

Leavy, P., 2011, Essentials of transdisciplinary research: Using problem-centred methodologies, Routledge, New York, NY.

Martin, V., 2017, Transdisciplinarity revealed: What librarians need to know, Libraries Libraries Unlimited, Santa Barbara, CA.

Maynes, M.J., Pierce, J.L. \& Laslett, B., 2008, Telling stories: The use of personal narratives in the social sciences and history, Cornell University Press, New York, NY.

Meda, L. \& Monnapula-Mapesela, M., 2016, 'Going wide, not wild: Varying conceptualizations of internationalization at a university of technology in South Africa', Journal of Studies in International Education 20(3), 282-294. https://doi. org/10.1177/1028315316637340

Mitchell, T.D., 2008, 'Traditional vs. critical service-learning: Engaging the literature to differentiate two models', Michigan Journal of Community Service Learning 14(2), 50-65.

Mokhele, M. \& Pinfold, N., 2020, 'Foundation for transdisciplinary education at Cape Peninsula University of Technology', The Journal for Transdisciplinary Research in Southern Africa 16(1), a749. https://doi.org/10.4102/td.v16i1.749

Montuori, A., 2013, 'The complexity of transdisciplinary literature reviews', Complicity: An International Journal of Complexity and Education 10(1/2), 45-55. https://doi. org/10.29173/cmplct20399

Mzangwa, S.T., 2016, 'Socio-economic inequalities, triple challenges and consequences of ineffective leadership in South Africa', Journal of Public Administration and Development Alternatives (JPADA) 1(1.1), 57-74.

Nicolescu, B., 2010, 'Methodology of transdisciplinarity - Levels of reality, logic of the include middle and complexity', Transdisciplinary Journal of Engineering and Science 1(1), 19-38. https://doi.org/10.22545/2010/0009

Nicolescu, B., 2014, 'Methodology of transdisciplinarity', World Futures 70(3-4), 186-199. https://doi.org/10.1080/02604027.2014.934631

Palmer, M., Owens, M. \& Sparks, L., 2006, 'Interdisciplinary (retail) research: The business of geography and the geography of business', Environment and Planning A: Economy and Space 38(10), 1775-1783. https://doi.org/10.1068/a3810com

Petersen, N. \& Osman, R., 2017, 'An introduction to service learning in South Africa', in R. Osman \& N. Petersen (eds.), Service learning in South Africa, pp. 2-32, Oxford University Press, Cape Town. 
Pinfold, N. \& Mokhele, M., 2019, 'Mapping memories through geographic information system: The case of St Mark's transdisciplinary service-learning project in District system: The case of St Mark's transdisciplinary service-learning project in District
Six, Cape Town', Alternation 29, 223-244. https://doi.org/10.29086/2519Six, Cape Town',
$5476 / 2019 /$ sp29a10

Ramaley, J.A., 2014, 'The changing role of higher education: Learning to deal with wicked problems', Journal of Higher Education Outreach and Engagement 18(3) wicked

Repko, A.E., 2008, Interdisciplinary research: Process and theory, Sage, Los Angeles, CA.

Scheepers, J., 2014, An integrated curriculum model for service-learning in faculties: Design implementation and quality, presentation (on behalf of CPUT's servicelearning unit) to CPUT's Faculty of Informatics and Design, June 19.

Sletto, B., 2010, 'Educating reflective practitioners: Learning to embrace the unexpected through service learning', Journal of Planning Education and Research 29(4), 403-415. https://doi.org/10.1177/0739456X10362771

Statistics South Africa, 2013, Millennium development goals: Country report 2013, Statistics South Africa, Pretoria, viewed 01 June 2021, from www.statssa.gov.za.

Stokols, D., Hall, K.L., Moser, R.P., Feng, A., Misra, S. \& Taylor, B.K., 2010, 'Cross disciplinary team science initiatives: Research, training, and translation', in R Frodeman, J.T. Klein, C. Mitcham \& J. B. Holbrook (eds.), The Oxford handbook of interdisciplinarity, pp. 471-493, Oxford University Press, New York, NY.
Thomson, A.M., Smith-Tolken, A.R., Naidoo, A.V. \& Bringle, R.G., 2011, 'Service learning and community engagement: A comparison of three national contexts', Voluntas: International Journal of Voluntary and Nonprofit organizations 22(2), 214-237. https://doi.org/10.1007/s11266-010-9133-9

Van der Westhuizen, M. \& Swart, I., 2015, 'The struggle against poverty, unemployment and social injustice in present-day South Africa: Exploring the involvement of the Dutch Reformed Church at congregational level', Stellenbosch Theological Journal 1(2), 731-759. https://doi.org/10.17570/stj.2015.v1n2.a35

Van Hulst, M., 2012, 'Storytelling, a model of and a model for planning', Planning Theory 11(3), 299-318. https://doi.org/10.1177/1473095212440425

Wall, S. \& Shankar, I., 2008, 'Adventures in transdisciplinary learning', Studies in Higher Education 33(5), 551-565. https://doi.org/10.1080/03075070802373008

Watson, V., 2002, Change and continuity in spatial planning: Metropolitan planning in Cape Town under political transition, Routledge, London.

World Bank, 2018, An incomplete transition: Overcoming the legacy of exclusion in South Africa, Republic of South Africa systematic country diagnostic, Report No. 125838-ZA, viewed n.d., from https://openknowledge.worldbank.org/bitstream/ handle/10986/29793/WBG-South-Africa-Systematic-Country-Diagnostic-FINALfor-board-SECPO-Edit-05032018. pdf?sequence=1\&isAllowed=y.

Wu, H. \& Zha, Q., 2018, 'A new typology for analysing the direction of movement in higher education internationalization', Journal of Studies in Internationa Education 22(3), 259-277. https://doi.org/10.1177/1028315318762582 